\title{
Analysis of EIF4G1 in ethnic Chinese
}

\author{
Kai Li', Bei-sha Tang 1,2,3, Ji-feng Guo 1,2, Ming-xing Lou', Zhan-yun Lv', Zhen-hua Liu', Yun Tian', \\ Cheng-yuan Song ${ }^{1}$, Kun $\mathrm{Xia}^{3}$ and Xin-xiang Yan ${ }^{1,2^{*}}$
}

\begin{abstract}
Background: Eukaryotic translation initiation factor 4-gamma 1 (EIF4G1) gene mutations have recently been reported in autosomal dominant, late-onset Parkinson's disease (LOPD). We carried out genetic analysis to determine the prevalence of EIF4G1 variants in an ethnic Chinese population and to better understand the association between EIF4G1 and PD.
\end{abstract}

Methods: We conducted a comprehensive genetic analysis of EIF4G1 in a cohort of 29 probands of autosomal dominant, LOPD families. Polymerase chain reaction (PCR) analysis and sequencing was carried out of the entire EIF4G1 exonic regions and exon-intron boundaries. Specific mutation and exonic variants were chosen for further sequencing in a case-control study including 503 sporadic PD and 508 healthy controls. Statistical significance was analyzed by the Chi-square test.

Results: Our analysis revealed three exonic variants (rs2230571, rs13319149 and rs2178403) and eight intronic variants across the entire EIF4G1 gene. No reported mutations were detected in EIF4G1 exonic regions. The synonymous coding variant rs2230571 in exon 27 and the eight intronic variants were not used for further sequencing, but the specific mutation c.3614G > A (p.R1205H) and the two nonsynonymous variants (rs13319149 and rs2178403) were chosen for further analysis in a case-control study. None of the 503 sporadic PD or 508 healthy controls carried p.R1205H, and there was no statistical significance in rs2178403 genotype or allele frequencies in EIF4G1 between the PD cases and the healthy controls ( $p=0.184$ and $p=0.774$, respectively; Chi-square test). The rs13319149 genotype in all PD cases and healthy controls was GG.

Conclusions: Our data indicate that in an ethnic Chinese population, the pathogenic mutation p.R1205H in EIF4G1 is not common and that EIF4G1 exonic variants rs2178403 and rs13319149 are not associated with PD. EIF4G1 does not appear to be a frequent cause of PD in this ethnic Chinese population.

Keywords: EIF4G1, Parkinson's disease, Ethnic Chinese

\section{Background}

Parkinson's disease (PD) is the second most common neurodegenerative movement disorder and is clinically characterized by the cardinal features of bradykinesia, resting tremor, rigidity, postural instability and responsiveness to dopaminergic therapy. Most PD patients are sporadic but approximately $5-10 \%$ are familial [1]. Although the etiology of PD still remains elusive, certain genes are known to influence PD susceptibility, for example, autosomal dominant PD is associated with SNCA

\footnotetext{
* Correspondence: xxyan1268@yahoo.com.cn

'Department of Neurology, Xiangya Hospital, Central south university, xiangya road, Changsha, China

${ }^{2}$ Neurodegenerative Disorders Research Centrer, Central South University, xiangya road, Changsha, China

Full list of author information is available at the end of the article
}

[2], LRRK2 [3], UCHL1 [4] and VPS35 [5,6], recessive parkinsonism with PRKN [7], PINK1 [8] and DJ-1 [9], and more complex forms of recessive parkinsonism with ATP13A2 [10], PLA2G6 [11] and FBXO7 [12]. Several techniques have been used to identify candidate genes in familial PD, including classic linkage analysis, positional cloning studies and recent exome sequencing $[2,5,6,13]$.

Recently, Chartier-Harlin et al. [14,15] performed genome-wide linkage analysis of a multi-incident French family presenting with autosomal dominant, late-onset PD (LOPD). They found that the mutation c.3614G > A (p.R1205H) in EIF4G1, encoding eukaryotic translation initiation factor 4G1 (eIF4G1), a component of the translation initiation complex eukaryotic translation initiation factor $4 \mathrm{~F}$ (eIF4F), caused the familial LOPD. The trans-

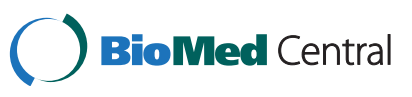

(C) 2013 Li et al.; licensee BioMed Central Ltd. This is an Open Access article distributed under the terms of the Creative Commons Attribution License (http://creativecommons.org/licenses/by/2.0), which permits unrestricted use, distribution, and reproduction in any medium, provided the original work is properly cited. 
Table 1 EIF4G1 gene variants in 29 probands of LOPD families

\begin{tabular}{|c|c|c|c|c|c|}
\hline \multicolumn{2}{|c|}{ Exonic/intronic variants } & \multirow{2}{*}{$\begin{array}{l}\text { Accession number } \\
\text { rs73187631 }\end{array}$} & \multirow{2}{*}{$\begin{array}{l}\text { Nucleotide change }^{\mathbf{a}} \\
\text { IVS2-182 a >t }\end{array}$} & \multirow[t]{2}{*}{ Amino acid change } & \multirow{2}{*}{$\begin{array}{l}\text { Frequency of variant in LOPD families (\%) } \\
7.41\end{array}$} \\
\hline 1 & Intron 2 & & & & \\
\hline 2 & Intron 3 & novel & IVS3 -44 a > g & & 1.85 \\
\hline 3 & Intron 4 & novel & IVS4 + $115 \mathrm{~g}>\mathrm{a}$ & & 3.70 \\
\hline 4 & Exon 7 & rs13319149 & c. $481 A>G$ & T161A & 100 \\
\hline 5 & Intron 9 & rs9846954 & IVS9 + 93 a >t & & 25.93 \\
\hline 6 & Intron 9 & novel & IVS9 + 75 indel $^{b}$ & & 7.41 \\
\hline 7 & Intron 9 & rs4912537 & IVS9-100 c >t & & 14.81 \\
\hline 8 & Exon 10 & rs2178403 & C. $1294 A>G$ & M432V & 55.56 \\
\hline 9 & Intron 15 & 1KG 3184041398 & IVS15 + 17c c t & & 1.85 \\
\hline 10 & Intron 18 & 1KG 3184043002 & IVS18 $+100 \mathrm{~g}>\mathrm{t}$ & & 1.85 \\
\hline 11 & Exon 27 & rs2230571 & c. $4005 C>T$ & $\mathrm{H} 1335 \mathrm{H}$ & 18.52 \\
\hline
\end{tabular}

${ }^{a}$ Human EIF4G1 cDNA sequence (RefSeq Accession number NM_198241.2) was used as the reference sequence.

${ }^{b}$ indel : acttgaac deletion; tgggtaccagagaa insertion. (i.e. acttgaac > ggtaccagagaa).

lation initiation complex is a large family $[16,17]$, including eukaryotic translation initiation factor 4E (eIF4E) and eukaryotic translation initiation factor $3 e$ (eIF3e) that interact with each other and conduct normal translation initiation activity $[14,18,19]$. In the Chartier-Harlin study [14], it was predicted that mutations p.A502V and p.R1205H disrupt eIF4G1 binding to eIF4E or eIF3e, resulting in PD. Subsequent sequencing and genotyping analysis also identified different EIF4G1 mutations in affected subjects with familial parkinsonism and idiopathic Lewy body disease in different populations.

To obtain a comprehensive view of the prevalence of EIF4G1 variants in an ethnic Chinese population, we conducted a comprehensive genetic screening of EIF4G1 in a Han Chinese group of subjects.

\section{Methods \\ Patients}

The study comprised 29 probands of PD families compatible with autosomal dominant inheritance (two or more PD cases in at least two consecutive generations) and 503 sporadic PD patients of Chinese Han ethnicity from Hunan, Hubei, Jiangxi, Sichuan and Chongqing provinces of China. All patients were consecutively recruited from the Department of Neurology of Xiangya Hospital (Central South University, State Key Laboratory of Medical Genetics of China) and the Neurodegenerative Disorders Research Center. A standard clinical neurological examination was performed for all patients by two neurologists, and a diagnosis of idiopathic PD was made according to the United Kingdom PD Brain Bank Criteria [20].

There were 13 male and 16 female PD patients among the 29 autosomal dominant, LOPD probands, with a mean age at onset of $50.33 \pm 9.56$ years (range, 4163 years). Of the 503 sporadic PD patients, 269 were male and 234 were female with a mean age at onset of $55.25 \pm 12.21$ years (range, $22-81$ years). The casecontrol study also included 508 healthy controls (268 males and 240 females; average age at examination, $56.95 \pm 15.20$ years, range, $25-88$ years) matched for age, gender, ethnicity and area of residence. The control subjects were healthy people from the Xiangya Hospital Medical Center, and healthy volunteers with no history of neurodegenerative diseases. A standard clinical neurological examination was performed on all control subjects, and a diagnosis of possible idiopathic PD was excluded according to the United Kingdom PD Brain Bank Criteria. There was no statistically significant difference in age or gender between patients and controls ( $p>0.05$, using Chi-square test). The study protocol was approved by the Ethics Committee of Central South University and written informed consent was obtained from all patients and controls.

Table 2 Genotype and allele frequencies of rs2178403 in PD and controls in Han Chinese

\begin{tabular}{|c|c|c|c|c|c|c|c|}
\hline \multirow[t]{2}{*}{$\mathbf{N}$} & \multicolumn{4}{|c|}{ Genotype (\%) } & \multicolumn{3}{|c|}{ Allele (\%) } \\
\hline & $\overline{A A}$ & AG & GG & $P$ value(df) & $A$ & G & $P$ value $(\mathrm{df}, \mathrm{OR})$ \\
\hline Patients 503 & $74(14.7)$ & $226(44.9)$ & $203(40.4)$ & $0.184^{a}(1)$ & $374(37.2)$ & $632(62.8)$ & $0.774^{\mathrm{b}}(1,1.027)$ \\
\hline Controls 508 & $87(17.1)$ & $210(41.4)$ & $211(41.5)$ & & $384(37.8)$ & $632(62.2)$ & \\
\hline
\end{tabular}

$P$ Values after correcting by binary logistic regression with age and gender using SPSS $17.0:^{a} p=0.713,{ }^{b} p=0.702$. 


\section{Genetic analysis}

Genomic DNA was extracted from peripheral blood using standard protocols. Polymerase chain reaction (PCR) analysis was carried out using 20 primer pairs (Additional file 1: Table S1, available online), and each PCR product was purified and directly sequenced in both forward and reverse directions on an ABI 3100 automated sequencer (Applied Biosystems, Foster City, CA). We initially sequenced the entire EIF4G1 exonic regions and exon-intron boundaries of the 29 probands of autosomal dominant, LOPD. Sequence alignment and analysis were carried out with Chromas 2.12 software (Technelysium Pty, Inc., Queensland, Australia).

\section{Statistical analysis}

Allele and genotype frequencies of PD and control groups were analyzed using the Chi-square test with SPSS 17.0 software (SPSS Inc., Chicago, IL, USA). A two-tailed test $p$-value of $<0.05$ was considered statistically significant.

\section{Results}

We identified three exonic variants and eight intronic variants across the entire EIF4G1 gene (Table 1). No reported mutations were detected in the EIF4G1 exonic regions in any of the 29 probands. One of the three exonic variants (exon 25, rs2230571) was synonymous, the other two (rs13319149 and rs2178403) were nonsynonymous.

Neither the synonymous variant nor the eight intronic variants could be sequenced, but the specific mutation p.R1205H and the two nonsynonymous variants underwent sequencing analysis in the 503 sporadic PD patients and 508 controls. None of the patients or controls carried the specific mutation p.R1205H. The nonsynonymous exonic variant rs2178403 was in Hardy-Weinberg equilibrium in both the patient and control groups using a goodness-of-fit Chi-square test. Genotype and allele frequencies of rs2178403 for all subjects are shown in Table 2. No statistically significant differences were observed regarding rs2178403 genotype or allele frequency between patients and controls $(p=0.184$ and $p=0.774$, respectively). Regarding the nonsynonymous exonic variant rs13319149, all patient and control genotypes were GG.

\section{Discussion}

EIF4G1 was confirmed as a candidate PD gene by Chartier-Harlin et al. [14,15], but recently three other groups identified EIF4G1 mutations in both PD patients and healthy controls [21-23]. This raises questions about the causality of the gene with regard to PD. In our comprehensive genetic analysis of EIF4G1, we also obtained similar negative results. The specific mutation p.R1205H, first identified by Chartier-Harlin, is important in PD for regulating cell survival in response to stressors $[14,15]$.
However, it was absent from all of our 503 sporadic PD cases and 508 healthy controls suggesting that different populations may have different pathogenic mutations. Alternatively, the effect of the same mutation may differ in different populations, as indicated by the presence of mutation p.R1205H in control individuals of a Central European population shown by Schulte et al. [23].

In the present study, exonic variants rs13319149 and rs2178403 showed no significant difference in either genotype or allele frequencies between PD patients and controls, suggesting that they are probably benign polymorphisms. Although EIF4G1 is considered a pathogenic gene of LOPD, our 29 probands were not typical of LOPD as the average age of onset was $50.33 \pm 9.56$ years. This may contribute to our negative results, together with the fact that our sample size was relatively small. Further larger-scale genetic studies should therefore be performed to validate our findings.

\section{Conclusions}

To our knowledge, this is the first study to assess the frequency of EIF4G1 variants in a cohort of Chinese PD patients and controls. Our results suggest that in this ethnic Chinese population, the pathogenic mutation p.R1205H in EIF4G1 is not common and that nonsynonymous exonic variants rs2178403 and rs13319149 are not associated with PD. Thus, it appears that EIF4G1 is not a frequent cause of PD in this ethnic Chinese population. Further large scale genetic and functional studies would be useful to establish EIF4G1 associations with PD.

\section{Additional file}

Additional file 1: Table S1. EIF4G1 Sequencing Primers.

\section{Abbreviations}

ATP13A2: ATPase type 13A2 gene; df: Degree of freedom; elF3e: Eukaryotic translation initiation factor 3e; elF4E: Eukaryotic translation initiation factor 4E; EIF4G1: Eukaryotic translation initiation factor 4-gamma 1 gene; FBXO7: F-box protein 7; LOPD: Late-onset Parkinson disease; LRRK2: Leucine-rich repeat kinase 2 gene; OR: Odds ratio; PCR: Polymerase chain reaction; PD: Parkinson disease; PINK1: PTEN-induced putative kinase 1 gene; PRKN: Parkin; PLA2G6: Phospholipase A2, group VI gene; SNCA: A-synuclein gene; UCHL 1: Ubiquitin carboxyl-terminal esterase L1; VPS35: Vacuolar protein sorting 35 gene.

\section{Competing interests}

The authors declare that they have no competing interests.

\section{Authors' contributions}

$\mathrm{KL}$ performed the genotyping, statistical analysis, and drafted the manuscript. $M X L, Z Y L, Z H L, Y T, C Y S$, and KX contributed to the collection of materials, participated in the study design and coordination, and drafted the manuscript. BST, JFG and XXY conceived the study, participated in its conceptual design and coordination, and drafted the manuscript. All authors read and approved the final manuscript.

\section{Acknowledgements}

This work was supported by grants from the Major State Basic Research Development Program of China (973 Program) (2011CB510000); and National 
Natural Science Foundation of China $(81171198,81130021$, 30971035, 30900469, 81000542). We would like to thank all PD patients and health control individuals participating in the study.

\section{Author details}

'Department of Neurology, Xiangya Hospital, Central south university, xiangya road, Changsha, China. ${ }^{2}$ Neurodegenerative Disorders Research Centrer, Central South University, xiangya road, Changsha, China. ${ }^{3}$ National Lab of Medical Genetics of China, xiangya road, Changsha, China.

Received: 12 September 2012 Accepted: 22 April 2013 Published: 26 April 2013

\section{References}

1. Wood-Kaczmar A, Gandhi S, Wood NW: Understanding the molecular causes of Parkinson's disease. Trends Mol Med 2006, 12(11):521-528.

2. Polymeropoulos MH, Lavedan C, Leroy E, Ide SE, Dehejia A, Dutra A, Pike B, Root $\mathrm{H}$, Rubenstein J, Boyer R, et al: Mutation in the alpha-synuclein gene identified in families with Parkinson's disease. Science 1997, 276(5321):2045-2047.

3. Paisan-Ruiz C, Jain S, Evans EW, Gilks WP, Simon J, van der Brug M, Lopez DMA, Aparicio S, Gil AM, Khan N, et al: Cloning of the gene containing mutations that cause PARK8-linked Parkinson's disease. Neuron 2004, 44(4):595-600.

4. Leroy E, Boyer R, Auburger G, Leube B, Ulm G, Mezey E, Harta G, Brownstein MJ, Jonnalagada S, Chernova T, et al: The ubiquitin pathway in Parkinson's disease. Nature 1998, 395(6701):451-452.

5. Vilarino-Guell C, Wider C, Ross OA, Dachsel JC, Kachergus JM, Lincoln SJ, Soto-Ortolaza Al, Cobb SA, Wilhoite GJ, Bacon JA, et al: VPS35 mutations in Parkinson disease. Am J Hum Genet 2011, 89(1):162-167.

6. Zimprich A, Benet-Pages A, Struhal W, Graf E, Eck SH, Offman MN, Haubenberger D, Spielberger S, Schulte EC, Lichtner P, et al: A mutation in VPS35, encoding a subunit of the retromer complex, causes late-onset Parkinson disease. Am J Hum Genet 2011, 89(1):168-175.

7. Kitada T, Asakawa S, Hattori N, Matsumine H, Yamamura Y, Minoshima S, Yokochi M, Mizuno Y, Shimizu N: Mutations in the parkin gene cause autosomal recessive juvenile parkinsonism. Nature 1998, 392(6676):605-608.

8. Valente EM, Abou-Sleiman PM, Caputo V, Muqit MM, Harvey K, Gispert S, Ali Z, Del TD, Bentivoglio AR, Healy DG, et al: Hereditary early-onset Parkinson's disease caused by mutations in PINK1. Science 2004, 304(5674):1158-1160.

9. Bonifati V, Rizzu P, van Baren MJ, Schaap O, Breedveld GJ, Krieger E, Dekker MC Squitieri $F$, Ibanez $P$, Joosse $M$, et al: Mutations in the DJ-1 gene associated with autosomal recessive early-onset parkinsonism. Science 2003, 299(5604):256-259.

10. Ramirez A, Heimbach A, Grundemann J, Stiller B, Hampshire D, Cid LP, Goebel I, Mubaidin AF, Wriekat AL, Roeper J, et al: Hereditary parkinsonism with dementia is caused by mutations in ATP13A2, encoding a lysosomal type 5 P-type ATPase. Nat Genet 2006, 38(10):1184-1191.

11. Paisan-Ruiz C, Bhatia KP, Li A, Hernandez D, Davis M, Wood NW, Hardy J, Houlden H, Singleton A, Schneider SA: Characterization of PLA2G6 as a locus for dystonia-parkinsonism. Ann Neurol 2009, 65(1):19-23.

12. Shojaee S, Sina F, Banihosseini SS, Kazemi MH, Kalhor R, Shahidi GA, Fakhrai-Rad H, Ronaghi M, Elahi E: Genome-wide linkage analysis of a Parkinsonian-pyramidal syndrome pedigree by $500 \mathrm{~K} \mathrm{SNP}$ arrays. Am J Hum Genet 2008, 82(6):1375-1384.

13. Polymeropoulos $M H$, Higgins JJ, Golbe LI, Johnson WG, Ide SE, Di lorio $G$ Sanges G, Stenroos ES, Pho LT, Schaffer AA, et al: Mapping of a gene for Parkinson's disease to chromosome 4q21-q23. Science 1996, 274(5290):1197-1199.

14. Chartier-Harlin MC, Dachsel JC, Vilarino-Guell C, Lincoln SJ, Lepretre F, Hulihan MM, Kachergus J, Milnerwood AJ, Tapia L, Song MS, et al: Translation initiator EIF4G1 mutations in familial Parkinson disease. Am J Hum Genet 2011, 89(3):398-406.

15. Chartier-Harlin MC, Dachsel JC, Hulihan MM, Kachergus J, Lepretre F, Levecque C: EIF4G1 mutations in familial parkinsonism. Parkinsonism Relat Disord 2009, 15:S145.

16. Silvera D, Arju R, Darvishian F, Levine PH, Zolfaghari L, Goldberg J, Hochman T, Formenti SC, Schneider R: Essential role for elF4Gl overexpression in the pathogenesis of inflammatory breast cancer. Nat Cell Biol 2009, 11(7):903-908.
17. Ramirez-Valle F, Braunstein S, Zavadil J, Formenti SC, Schneider RJ: elF4G links nutrient sensing by mTOR to cell proliferation and inhibition of autophagy. J Cell Biol 2008, 181(2):293-307.

18. Sonenberg N, Hinnebusch AG: Regulation of translation initiation in eukaryotes: mechanisms and biological targets. Cell 2009, 136(4):731-745.

19. LeFebvre AK, Korneeva NL, Trutschl M, Cvek U, Duzan RD, Bradley CA, Hershey JW, Rhoads RE: Translation initiation factor elF4G-1 binds to elF3 through the elF3e subunit. J Biol Chem 2006, 281(32):22917-22932.

20. Hughes AJ, Daniel SE, Kilford L, Lees AJ: Accuracy of clinical diagnosis of idiopathic Parkinson's disease: a clinico-pathological study of 100 cases. J Neurol Neurosurg Psychiatry 1992, 55(3):181-184.

21. Tucci A, Charlesworth G, Sheerin UM, Plagnol V, Wood NW, Hardy J: Study of the genetic variability in a Parkinson's Disease gene: EIF4G1. Neurosci Lett 2012, 518(1):19-22.

22. Lesage $\mathrm{S}$, Condroyer $\mathrm{C}$, Klebe $\mathrm{S}$, Lohmann E, Durif F, Damier $\mathrm{P}$, Tison $\mathrm{F}$, Anheim M, Honore A, Viallet $F$, et al: EIF4G1 in familial Parkinson's disease: pathogenic mutations or rare benign variants? Neurobiol Aging 2012, 33(9):2231-2233.

23. Schulte EC, Mollenhauer B, Zimprich A, Bereznai B, Lichtner $P$, Haubenberger D, Pirker W, Brucke T, Molnar MJ, Peters A, et al: Variants in eukaryotic translation initiation factor $4 \mathrm{G} 1$ in sporadic Parkinson's disease. Neurogenetics 2012, 13(3):281-285.

doi:10.1186/1471-2377-13-38

Cite this article as: Li et al:: Analysis of EIF4G1 in ethnic Chinese. BMC Neurology 2013 13:38.

\section{Submit your next manuscript to BioMed Central and take full advantage of:}

- Convenient online submission

- Thorough peer review

- No space constraints or color figure charges

- Immediate publication on acceptance

- Inclusion in PubMed, CAS, Scopus and Google Scholar

- Research which is freely available for redistribution 